\title{
Age And Growth Of Wild Suminoe (Crassostrea Ariakensis, Fugita 1913) And Pacific (C-Gigas, Thunberg 1793) Oysters From Laizhou Bay, China
}

JM Harding

Roger L. Mann

Virginia Institute of Marine Science

Follow this and additional works at: https://scholarworks.wm.edu/vimsarticles

Part of the Marine Biology Commons

\section{Recommended Citation}

Harding, JM and Mann, Roger L., "Age And Growth Of Wild Suminoe (Crassostrea Ariakensis, Fugita 1913) And Pacific (C-Gigas, Thunberg 1793) Oysters From Laizhou Bay, China" (2006). VIMS Articles. 451. https://scholarworks.wm.edu/vimsarticles/451 


\title{
AGE AND GROWTH OF WILD SUMINOE (CRASSOSTREA ARIAKENSIS, FUGITA 1913) AND PACIFIC (C. GIGAS, THUNBERG 1793) OYSTERS FROM LAIZHOU BAY, CHINA
}

\author{
JULIANA M. HARDING* AND ROGER MANN \\ Department of Fisheries Science, Virginia Institute of Marine Science, College of William and Mary, \\ P.O. Box 1346, Gloucester Point, Virginia 23062
}

\begin{abstract}
Shell height at age estimates from Suminoe (Crassostrea ariakensis) and Pacific (C. gigas) oysters from a natural oyster reef in Laizhou Bay, China were compared with shell height at age estimates from triploid $C$. ariakensis of known age from the Rappahannock River, Virginia. C. ariakensis and C. gigas reach shell heights in excess of $76 \mathrm{~mm}$ (3 inches) within 2 years after settlement regardless of the source location. This fast growth appears to continue through at least age 4 or age 5 in wild individuals, because the growth trajectories for both species had not reached asymptotic height in the oldest individuals collected. Estimates of the asymptotic maximum height $\left(\mathrm{SH}_{\max }\right.$ ) from fitted Von Bertalanffy (VB) growth models were greatest for Chinese C. ariakensis (244.0 $\mathrm{mm}$, standard error of the mean [SE] 30.4) and near the maximum shell height $(227.0 \mathrm{~mm})$ measured at the time of collection. Maximum shell heights measured on live Chinese C. gigas $(173.0 \mathrm{~mm})$ and Rappahannock C. ariakensis $(190.0 \mathrm{~mm})$ were also within the standard error estimates for the $\mathrm{SH}_{\max }$ estimates from the fitted VB models for Chinese C. gigas (158.6 mm, SE 20.3) and Rappahannock C. ariakensis (183 mm, SE 19.1). Fitted VB growth curves were not significantly different between species within the same habitat, within species in different habitats or between species in different habitats. The ratio of shell height to shell width and shell height to shell inflation for triploid $C$. ariakensis was significantly less than similar ratios observed in wild C. ariakensis and $C$. gigas oysters.
\end{abstract}

KEY WORDS: Suminoe oyster, Crassostrea ariakensis, Pacific oyster, Crassostrea gigas, age determination, bivalves, oysters, growth rates, resilium

\section{INTRODUCTION}

Bivalves carry a complete record of their lives in their shells (Pannella \& MacClintock 1968, Lutz \& Rhoads 1980, Richardson 2001). Environmental changes as well as seasonal changes in biology and physiology are recorded in the shell structure as external rings, internal lines and growth increments or both (e.g., Pannella \& MacClintock 1968, Lutz \& Rhoads 1980, Ropes 1985, Richardson 2001). Using the terminology of Richardson (2001), a growth line is an internal line deposited once a year (annually), whereas the annual growth increment is the distance separating adjacent growth lines. In oysters, internal growth lines may be observed in the resilium of the hinge structure (Richardson et al. 1993a, 1993b, Kirby et al. 1998, Richardson 2001) and in the middle homogenous shell layers. The resilium is protected from damage or erosion by the valves. During periods of reduced shell growth, the ligament growth also slows producing growth lines in both shell and resilium (Richardson 2001). In temperate oysters, the annual growth cycle includes one thick, grey growth line deposited in between white growth increments (Richardson et al. 1993a). Enumerating the thick grey growth lines within a resilium or shell cross section provides an estimate of age (years) for the oyster (Richardson et al. 1993a, 1993b, Kirby et al. 1998, Richardson 2001).

Pacific (Crassostrea gigas, Thunberg 1793) oysters are cultured for commercial purposes around the world with initial introductions often made to supplement native oyster stocks (see reviews by Mann 1981, Mann et al. 1991, Shatkin et al. 1997). In recent years, Suminoe (C. ariakensis, Fugita 1913) oysters have also been proposed as candidates for commercial aquaculture and/ or introductions to supplement native oyster stocks (e.g., Langdon \& Robinson 1996, Hallerman et al. 2002) Whereas little is known about the population age structure of wild populations of either species in natural reef settings in their native Asian waters, some

*Corresponding author. E-mail: jharding @ vims.edu data on growth rates in native waters are available. Zhang and Lou (1956, reported by Zhou \& Allen 2003) report Chinese $C$. ariakensis reaching sizes of $100-160 \mathrm{~mm}$ shell height in $2-3 \mathrm{y}$, whereas Fujimori (1929, reported by Cahn 1950) describes Japanese C. ariakensis reaching 197-mm shell height at ages of 6 y; C. ariakensis from China and Japan are described as large reaching sizes in excess of $200 \mathrm{~mm}$ shell height (Torigoe 1981).

The observed morphology of these oysters is variable. The morphology of $C$. ariakensis has been described as discoid (Ahmed 1971) and oval or rounded with relatively flat shell layers with only the left valve concave (Wakiya 1929, Torigoe 1981). Wakiya (1929) describes shells of $C$. ariakensis from soft mud habitats as "extremely elongated" and difficult to distinguish from C. gigas found on mud bottoms. C. gigas are also described as large (reaching shell heights $>400 \mathrm{~mm}$, Torigoe 1981) but both valves are concave with rippled shell layers (Torigoe 1981, Langdon \& Robinson 1996). Torigoe (1981) describes C. gigas as "oval to spatulate," but Wakiya (1929) describes adult $C$. gigas as "extremely elongated".

The objectives of this study are to describe shell morphology, shell height at age relationships and growth curves for wild $C$. ariakensis and $C$. gigas specimens collected concurrently from a natural population of reef oysters in Laizhou Bay, Gulf of Bohai, China and compare these data with shell morphology, shell height at age relationships, and growth curves for triploid $C$. ariakensis grown in Chesapeake Bay, USA.

\section{METHODS}

\section{Sample Collection}

Oysters of both species were collected from the same natural intertidal oyster reef in Laizhou Bay, Gulf of Bohai, China $\left(37^{\circ} 14^{\prime} 38.0,119^{\circ} 03^{\prime} 29.9\right)$ during a quadrat survey conducted in June 2004 by Dr. Mark Luckenbach (Virginia Institute of Marine Science (VIMS), Eastern Shore Laboratory) and Dr. Christopher Richardson (University of Wales Bangor, Menai Bridge). Ambient 
salinities were $30 \mathrm{ppt}$ at the time of collection. Oyster shells were separated from meats in the field at the time of collection. Shells were labeled, bagged and shipped as valve pairs corresponding to individuals. The species co-occurred on the reef and were distinguished from each other by genetic analyses (mitochondrial 16Sbased molecular key, per Banks et al. 1993) of tissue samples conducted by Dr. Ryan Carnegie (VIMS, Department of Environmental and Aquatic Animal Health). A total of 11 C. ariakensis individuals and 186 C. gigas individuals were identified from this collection on the basis of genetic analyses.

Four triploid $C$. ariakensis were collected from the lower Rappahannock River, Virginia during May 2004 as the remnant of a controlled field experiment conducted with aquacultured triploid C. ariakensis in 2001 (Dr. J. Wesson, Virginia Marine Resources Commission). These animals were spawned at VIMS in June 2000 (Dr. S. K. Allen, VIMS Aquaculture Genetics and Breeding Technology Center, pers. comm.); thus when they were collected and again certified as triploid in May 2004 they were approximately 4 years old.

\section{Laboratory Methods}

The hinge structure and shell morphology of each individual oyster was examined to evaluate suitability for sectioning and age estimation. Oysters in which the resilium, adductor muscle scar and growth edge on the left valve that formed a straight line were deemed suitable for aging and were set aside. A total of nine Chinese $C$. ariakensis and 19 Chinese $C$. gigas were suitable for estimation of age and growth rates. All four of the Rappahannock triploid $C$. ariakensis were used for age estimation.

The shells for estimation of age and growth rates were gently cleaned to remove attached epifauna using a sonicator. Measurements of shell height ( $\mathrm{SH}$, maximum dimension from the hinge to the growth edge, mm), maximum shell width ( $\mathrm{SW}$, maximum dimension perpendicular to the hinge across one valve, $\mathrm{mm}$ ) and maximum shell inflation (SI, maximum dimension perpendicular to the hinge across both valves, $\mathrm{mm}$ ) were made for each individual (Fig. 1). The ratios of (1) SH to SW and (2) SH to SI were calculated for each individual as metrics to describe shell shape. SH:SW ratios near 1 indicate a disk shaped or round individual, whereas SH:SW ratio values $>2$ are indicative of individuals that are long and narrow. SH:SI ratios provide an index of cupping or depth. SH:SI ratio values near 1 indicate an individual that is as deep or cupped as it is long (a spherical oyster), whereas higher $\mathrm{SH}$ :SI values describe oysters that are longer than they are deep. SH:SW and SH:SI ratios were compared across species within a site (Chinese $C$. ariakensis vs. Chinese $C$. gigas) and across sites within a species (Chinese vs. Rappahannock $C$. ariakensis) using 1-way ANOVAs with significance values set at $P=0.05$ a priori.

Shells were sectioned from hinge to the growth edge along a straight line that included the resilium and adductor muscle scar (the major axis of growth, Fig. 1 (a) using a diamond blade saw. Shell cross-sections were polished using wetable carborundum disks (240 through 600 grit) and diamond polishing suspension (Buehler Metadai, 6 and $1 \mu \mathrm{m}$ suspension). Shells were allowed to dry thoroughly after polishing before examination for growth signatures.

The section of the left valve containing the bulk of the adductor muscle scar was used for shell cross-section evaluation. The number of growth lines within each shell cross section were counted by following the thick grey lines that were continuous from the hinge
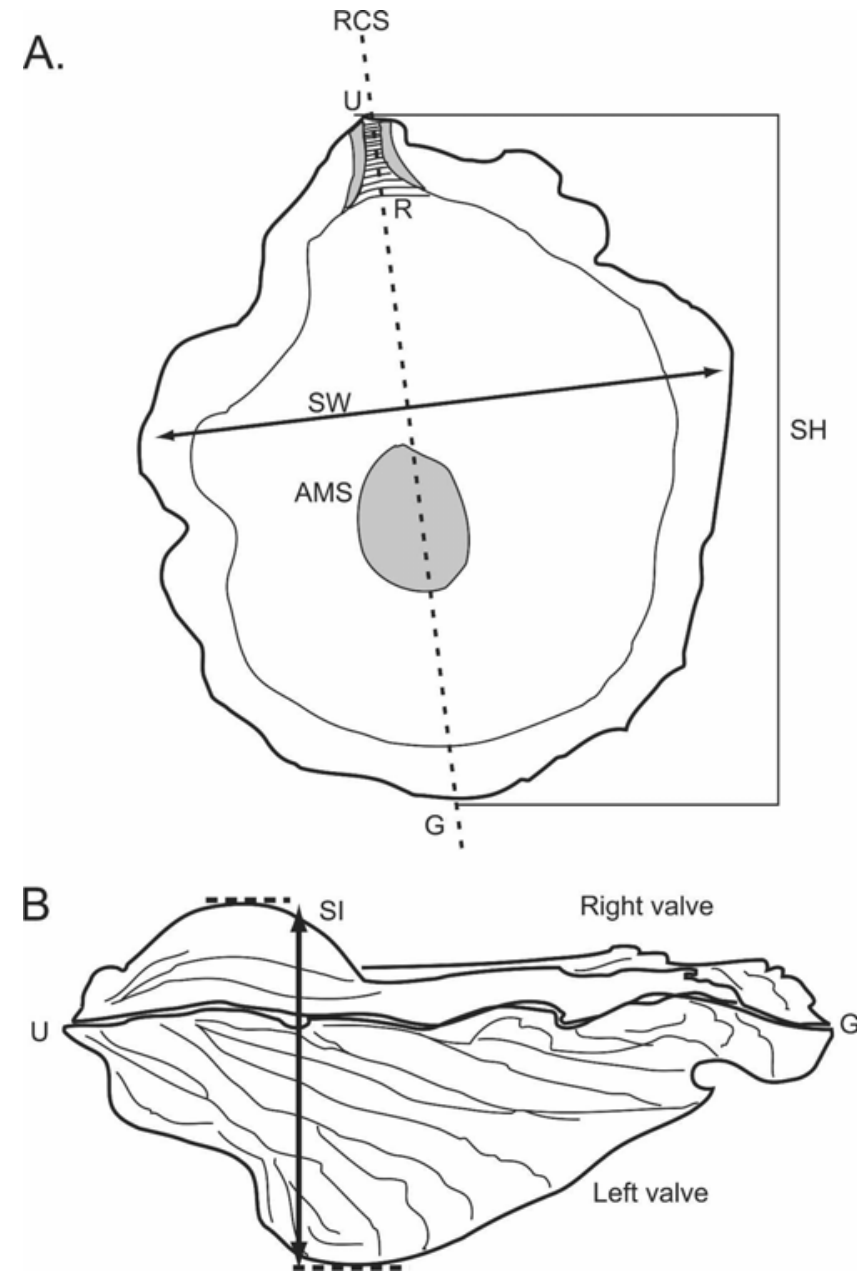

Figure 1. (A) Sketch of the left valve of a Crassostrea shell with the umbo (U), resilium (R), and adductor muscle scar (AMS) shown as reference points. Morphological measurements made for each shell are shown including shell height $(\mathrm{SH}, \mathrm{mm})$, shell width $(\mathrm{SW})$, and shell inflation (SI). After morphological measurements were made, a radial cross section (RCS) was made for each shell following the growth trajectory through the resilium (R) and AMS to the growth edge (G). (B) Sketch of a valves of a Crassostrea shell in profile showing where the measurement for shell inflation (SI) was made.

to the outer shell layer throughout the valve radial cross section (Fig. 2a). Lines visible in the cross section had to also be visible in the resilium structure to be included (Fig. 2b). The position of growth lines along the radial cross section in relation to the resilium of the hinge ligament provides a growth curve for individual animals. The distance from the hinge to the emergence of a growth line in the shell exterior of the radial cross section was measured $(\mathrm{mm})$ for each shell. The resilium was used to validate cross section lines given the foliation and ornamentation found in the shells of larger specimens. Shell height $(\mathrm{mm})$ at age (yr) curves were plotted for populations based on the sequential measurements of growth lines (height at age) made from left valve cross sections from a size range of individuals.

Population growth curves (age (yr), shell height $(\mathrm{mm})$ ) were fitted using the von Bertalanffy (VB) model (von Bertalanffy 1938) with nonlinear least squares regression. This model describes maximum growth and does not assume rotational symmetry about an inflection point (Brown \& Rothery 1993). It has been 


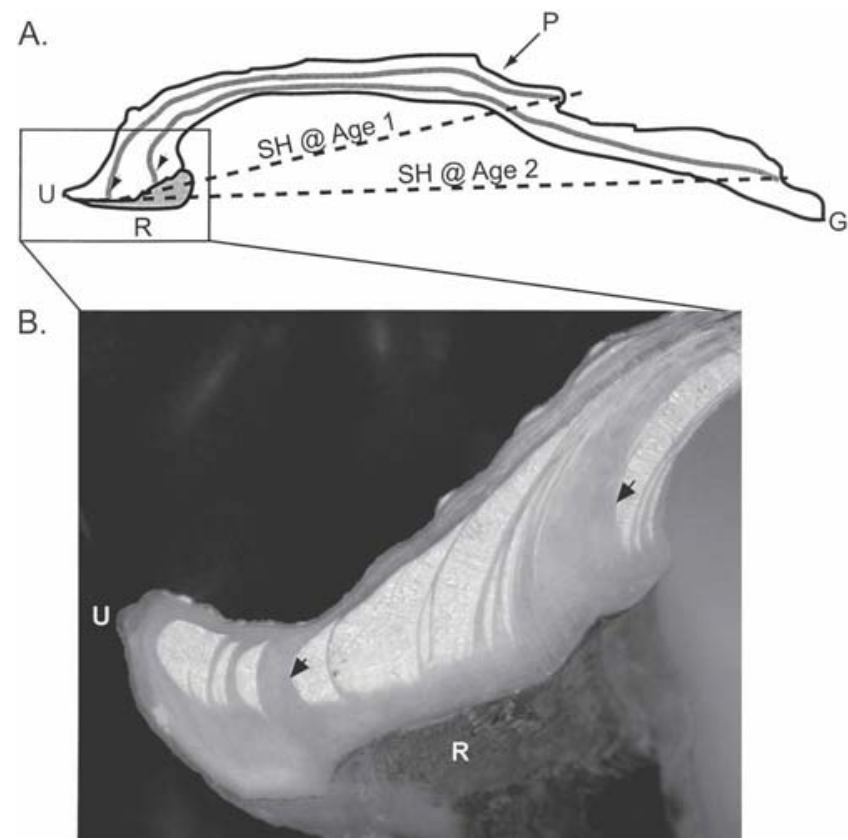

Figure 2. A. Sketch of a radial cross section of a Crassostrea left valve showing the annual growth lines (black arrows). Shell height at age measurements were made along axis U-G from the umbo to locations where the annual growth lines ended at the periostracum (P). B. Photograph of a representative resilium radial cross section from a 2-yearold $C$. gigas with the annual growth lines marked (black arrows).

used extensively to describe the growth of other species of shellfish (e.g., Spisula solidissima, Sephton \& Bryan 1990; Rangia cuneata, Fritz et al. 1990, Mercenaria mercenaria, Jones et al. 1990, Devillers et al. 1998, Ostrea edulis, Richardson et al. 1993a and Tiostrea (=Ostrea) lutaria, Richardson et al. 1993b). The model equation is:

$$
\mathrm{SH}_{\mathrm{t}}=\mathrm{SH}_{\max }\left(1-\mathrm{e}^{-\mathrm{k}\left[\mathrm{t}-\mathrm{t}_{0}\right]}\right)
$$

where $\mathrm{SH}_{\mathrm{t}}$ is the shell height at time $\mathrm{t}, \mathrm{SH}_{\max }$ is the maximum or asymptotic shell height, $\mathrm{t}_{0}$ is the size at time 0 , and $\mathrm{k}$ is a rate constant.

The fitted VB growth curves for populations of Chinese $C$. ariakensis, Chinese $C$. gigas, and cultured Rappahannock $C$. ariakensis were compared as pairs using the nonlinear coincident curve method described by Haddon (2001) based on Chen et al. (1992) and Zar (1996). This method compares two curves using the analysis of the residual sum of squares to test if two or more nonlinear curves are statistically different (Haddon 2001).

\section{RESULTS AND DISCUSSION}

\section{Morphology}

C.ariakensis from the Rappahannock River were more cupped than similarly sized individuals of either species from China as indicated by inflation measurements and SH:SI ratios (Table 1, Fig. 3, Fig. 4). The triploid Rappahannock River individuals were discoid (plate-like) when viewed from above as indicated by SH:SW ratios near 1 (Table 1, Fig. 3, 4). Ratios of SH:SW and $\mathrm{SH}$ :SI for Rappahannock C. ariakensis were significantly less than the same ratios for Chinese $C$. ariakensis (ANOVAs, DF $=1, \mathrm{~F}$ $=28.1$ (SH:SW) and $\mathrm{F}=8.86(\mathrm{SH}: \mathrm{SI}), P<0.05)$. Ratios of SH:SW and SH:SI from Chinese $C$. ariakensis and $C$. gigas were similar (ANOVAs, $\mathrm{DF}=1, \mathrm{~F}=0.73(\mathrm{SH}: \mathrm{SW}$ ) and $\mathrm{F}=0.47$ (SH:SI), $P>0.40$ ). Ratios from all four species and site combinations satisfied assumptions of homogeneity and normality without transformation. The wild Chinese $C$. ariakensis and $C$. gigas were typically long (SH), narrow (SW), and flatter in profile (SI) with higher SH:SW and SH:SI ratios than the Rappahannock River C. ariakensis (Table 1. Fig. 3, 4). The descriptions and photographs of $C$. ariakensis provided by Cahn (1950) and Torigoe (1981) from Ariake Bay, Japan are similar in terms of shape (tongue-like) and $\mathrm{SH}: \mathrm{SW}$ ratio to the large Chinese $C$. ariakensis and $C$. gigas examined in this study (Table 1, Fig. 3A to $F, 4)$.

\section{Shell Height at Age}

Chinese $C$. ariakensis and $C$. gigas displayed overlap in the range of observed shell heights at age with each other and with the triploid $C$. ariakensis from the Rappahannock River, Virginia (Table 2). C. ariakensis and $C$. gigas reach shell heights in excess of $76 \mathrm{~mm}$ ( 3 inches) within 2 years after settlement (Table 2, Fig. $5)$ regardless of the source location. This fast growth appears to continue through at least Age 4 (C. gigas, Fig. 5) and Age 5 (C. ariakensis, Fig. 5) in wild individuals because the growth trajectory for both species had not begun to flatten in the oldest individuals collected (Fig. 5). The observed shell height ranges for each age class (Table 2) are within the ranges of previously published reports of shell heights at age for both species (Table 3). The triploid C.ariakensis in the Rappahannock River 2001 to 2004 followed a growth trajectory similar to that reported for Ariake Bay Japan by Cahn (1950, from Fujimori 1929, Fig. 5). The Rappahannock animals had not reached asymptotic shell height when they were collected in May 2004 (Fig. 5).

The observed range in shell heights at Age 1 for the Chinese oysters may be the result of differences in the timing of individual

TABLE 1.

Summary of morphological measurements made on individual wild diploid $C$. gigas and $C$. ariakensis from Laizhou Bay, China and cultured triploid $C$. ariakensis from the Rappahannock River, USA. Measurements were made for shell height (SH), shell width (SW), and shell thickness or inflation (SI) as shown in Figure 1 and explained in the text. Ranges for each measurement type (SH, SW, SI) are presented for each species by habitat with average ratio and standard error of the mean (SE) values.

\begin{tabular}{llrrrrrr}
\hline \hline \multicolumn{1}{c}{ Site } & Species & $\boldsymbol{n}$ & $\begin{array}{c}\text { SH Range } \\
(\mathbf{m m})\end{array}$ & $\begin{array}{c}\text { SW Range } \\
(\mathbf{m m})\end{array}$ & $\begin{array}{c}\text { SI Range } \\
(\mathbf{m m})\end{array}$ & $\begin{array}{c}\text { Average SH:SW } \\
\text { Ratio (SE) }\end{array}$ & $\begin{array}{c}\text { Average SH:SI } \\
\text { Ratio }(\mathbf{S E})\end{array}$ \\
\hline Laizhou Bay, China & C. ariakensis & 9 & $113-227$ & $60-135$ & $26.3-72.0$ & $1.79(0.07)$ & $4.01(0.30)$ \\
& C. gigas & 19 & $38-173$ & $35-107$ & $25.0-50.0$ & $1.92(0.09)$ & $3.74(0.23)$ \\
Rappahannock River, US & C. ariakensis & 4 & $170-190$ & $145-157$ & $55.1-79.6$ & $1.19(0.03)$ & $2.57(0.23)$ \\
\hline
\end{tabular}



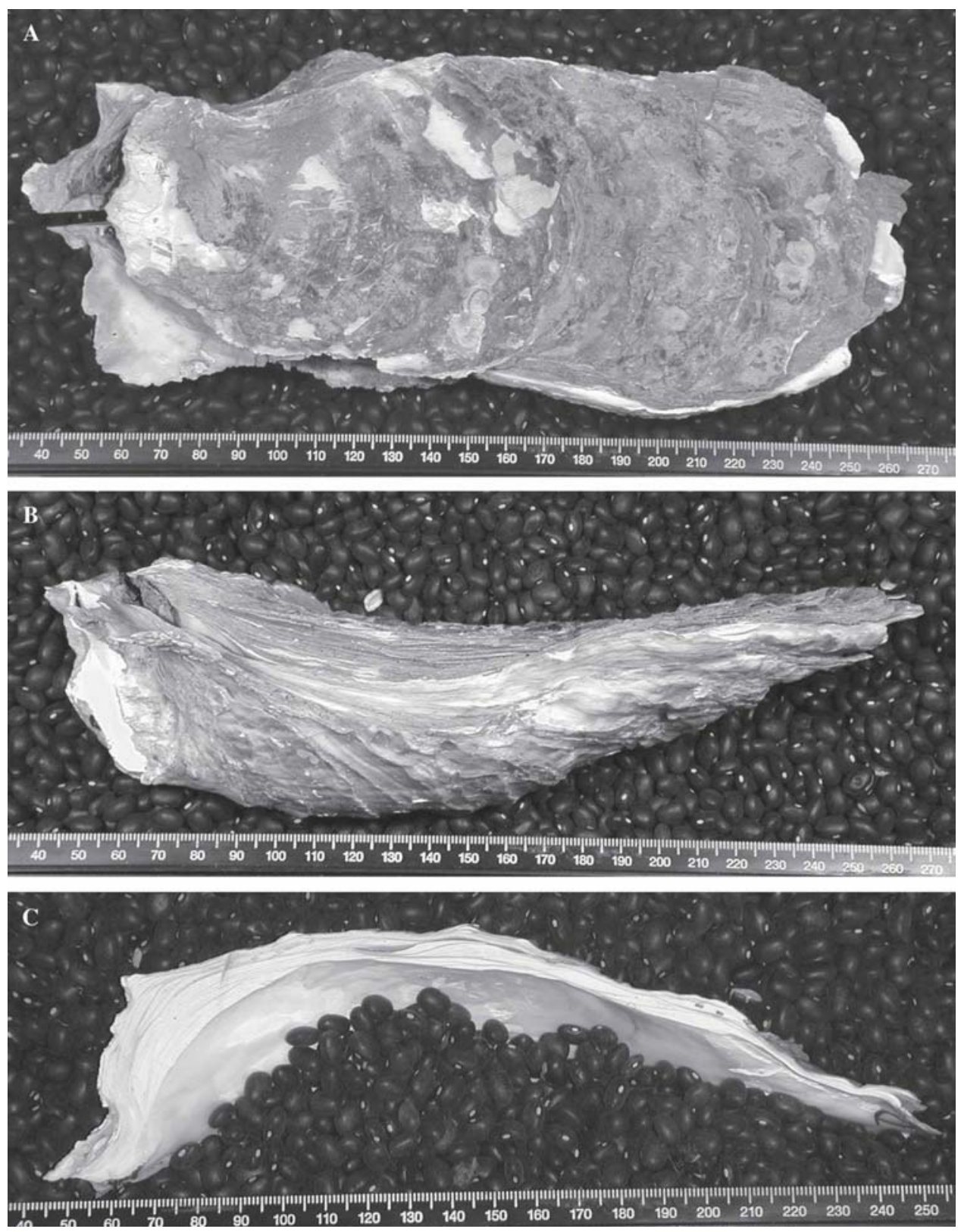

Figure 3. Photographs of representative specimens from China and the Rappahannock River, Virginia. A to $\mathrm{C}$, Chinese C. ariakensis, $\mathrm{SH}=227 \mathrm{~mm}$.

recruitment. Potential differences in the timing of spawning (Perdue \& Erickson 1984, Langdon \& Robinson 1996) and recruitment between species may be offset by differences in the growth rates of each species at temperatures less than $25^{\circ} \mathrm{C}$. Whereas recruits of both species grow faster at $25^{\circ} \mathrm{C}$ than at $15^{\circ} \mathrm{C}, \mathrm{C}$. gigas spat growth is less at $20^{\circ} \mathrm{C}$ than at $25^{\circ} \mathrm{C}$ and $C$. ariakensis spat grow as fast at $20^{\circ} \mathrm{C}$ as they do at $25^{\circ} \mathrm{C}$ (Langdon \& Robinson 1996). C. gigas that settle early in the season may stop growing earlier than conspecific $C$. ariakensis because of differences in thermal physiology. Although $C$. ariakensis may recruit later, they are able to grow at lower temperatures than $C$. gigas and the relatively extended growing window probably offsets differences in the timing of recruitment resulting in the observed overlap in size range $(C$. gigas: $27-55 \mathrm{~mm} \mathrm{SH}$, C. ariakensis: $27-57 \mathrm{~mm} \mathrm{SH}$ ) when the first growth line (Age 1) was deposited.

\section{VB Growth Model Coefficients and Model Fitting}

Fitted VB growth curves (Fig. 6) were not significantly different between species within the same habitat (Chinese $C$. gigas vs. C. ariakensis, $\mathrm{F}=2.2, P=0.10$, degrees of freedom $=71$ ), within species in different habitats (Chinese $C$. ariakensis vs. Rappahannock $C$. ariakensis, $\mathrm{F}=1.13, P=0.35$, $\mathrm{df}=45$ ) or between species in different habitats (Chinese $C$. gigas vs. Rappahannock $C$. ariakensis, $\mathrm{F}=0.93, P=0.43$, df $=55$ ).

Estimates of the asymptotic maximum height $\left(\mathrm{SH}_{\max }\right)$ were greatest for Chinese C. ariakensis $(244.0 \mathrm{~mm}$, SE 30.41) and near the maximum shell height $(227.0 \mathrm{~mm})$ measured at the time of collection (Fig. 6, Table 4). Maximum shell heights measured on live Chinese $C$. gigas $(173.0 \mathrm{~mm})$ and Rappahannock $C$. ariakensis $(190.0 \mathrm{~mm})$ were also within the standard error estimates for the 

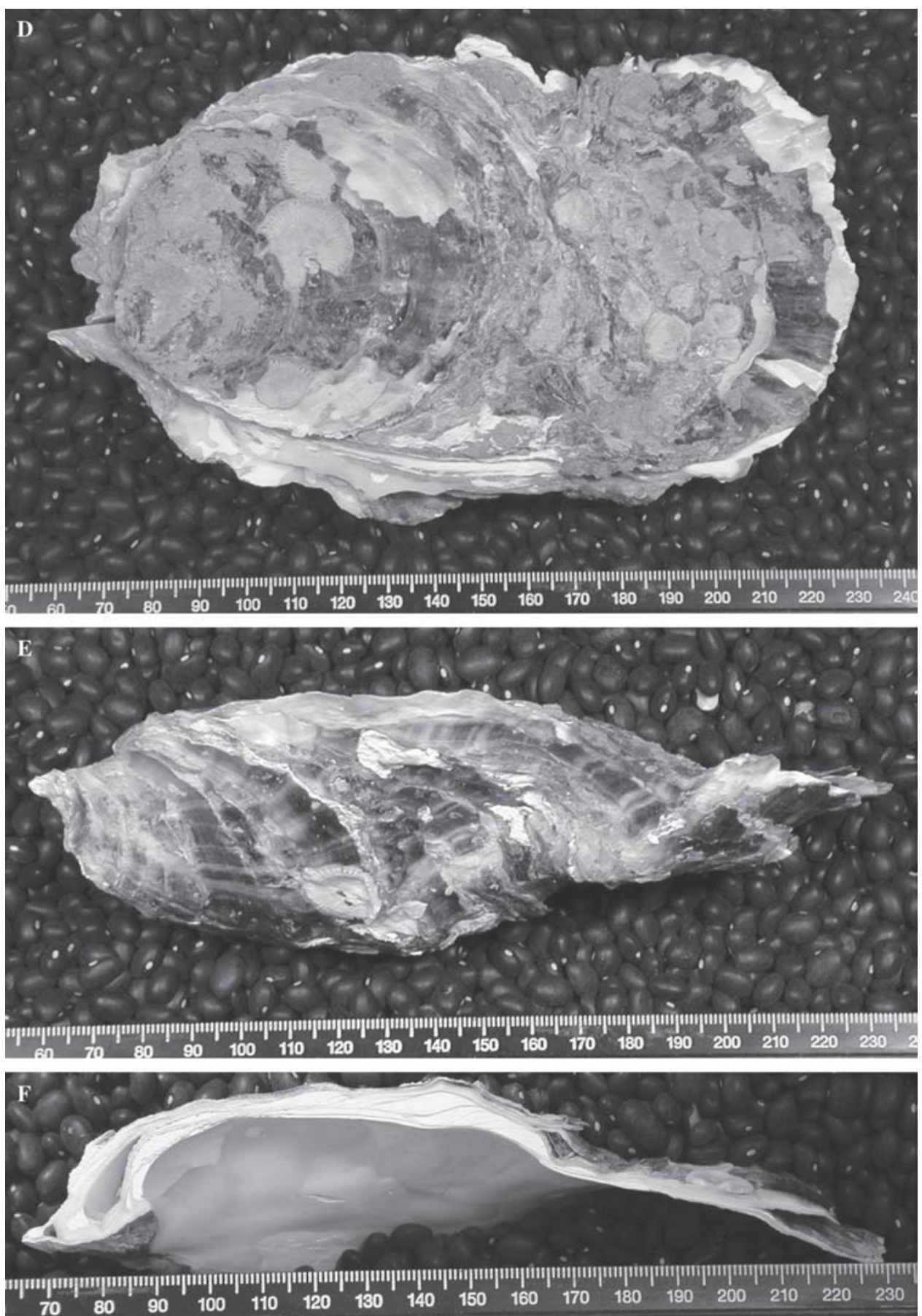

Figure 3. D to F, Chinese $C$. gigas, $\mathrm{SH}=165 \mathrm{~mm}$.

$\mathrm{SH}_{\max }$ estimates from the fitted VB models for Chinese $C$. gigas (158.6 mm, SE 20.25) and Rappahannock C. ariakensis $(183 \mathrm{~mm}$, SE 19.14; Table 4). The reported $\mathrm{SH}_{\max }$ estimates for $C$. ariakensis (Table 4) are within the range of shell heights reported for $C$. ariakensis from Ariake Bay, Japan (Cahn 1950: 240 mm; Torigoe 1981: $200 \mathrm{~mm}$ ). The $\mathrm{SH}_{\max }$ estimates for $C$. gigas (Table 4) are smaller than the reported maximum size range for Japan (Cahn 1950: Tokoro, 400 mm; Torigoe 1981: Ariake Bay, $448 \mathrm{~mm}$ ). The lack of representation of older age classes in the wild population and the fact that 13 out of the 19 C. gigas examined were 2 years old or less with only one 4 year old available resulted in dispro- portionate representation of younger individuals and uneven sample sizes across the age distribution, which may have skewed the estimate of asymptotic height towards the smaller individuals (Fig. 5 and 6, Tables 2 and 4).

The $\mathrm{k}$ model parameter specifies the curvature of the fitted growth line (Gallucci \& Quinn 1979) and is associated with the rate at which the organism approaches maximum size (Gallucci \& Quinn 1979). Observed k values (Table 4) for C. ariakensis were 0.33 (Chinese, diploid) and 0.55 (Rappahannock triploid), respectively with a k value of 0.68 observed for the $C$. gigas. Coefficients of determination $\left(\mathrm{R}^{2}\right)$ for the Chinese and Rappahannock $C$. ari- 

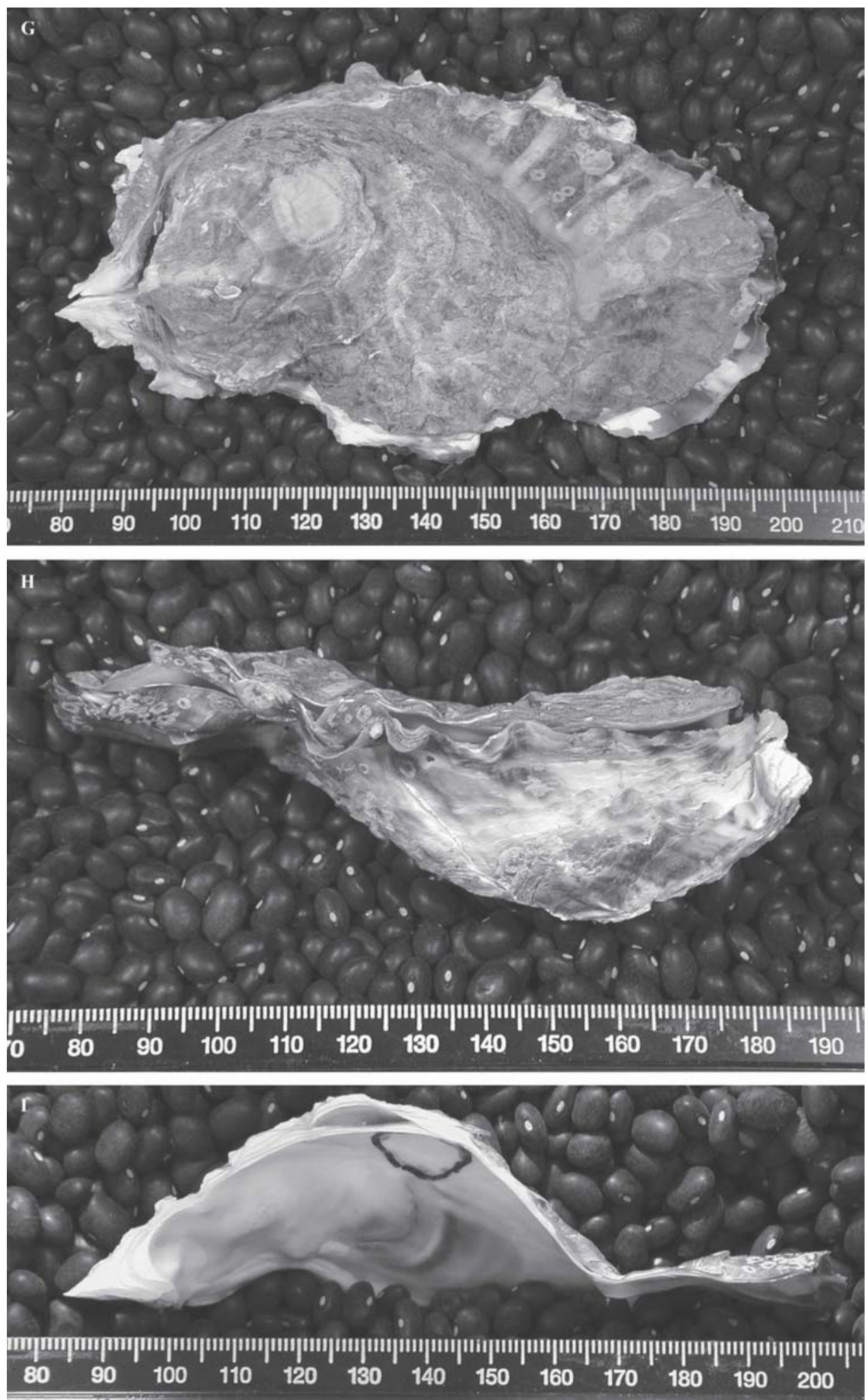

Figure 3. G to I, Chinese $C$. gigas, $\mathrm{SH}=126 \mathrm{~mm}$.

akensis were greater than or equal to 0.94 (Table 4). The $C$. gigas coefficient of determination was 0.89 and this may be reflective of the fact that most of the specimens examined (17/19) were less than 3 y old (Fig. 5, Tables 2 and 4). The relative under representation or absence of older C. gigas at or near asymptotic height is reflected in the high $\mathrm{k}$ value (0.68) and lower coefficient of determination (0.89) relative to the $C$. ariakensis populations both of which had more balanced distribution of individuals across age classes (Fig. 5, Tables 2 and 4).

Salinities in Laizhou Bay (30 ppt) are higher than those typi- 

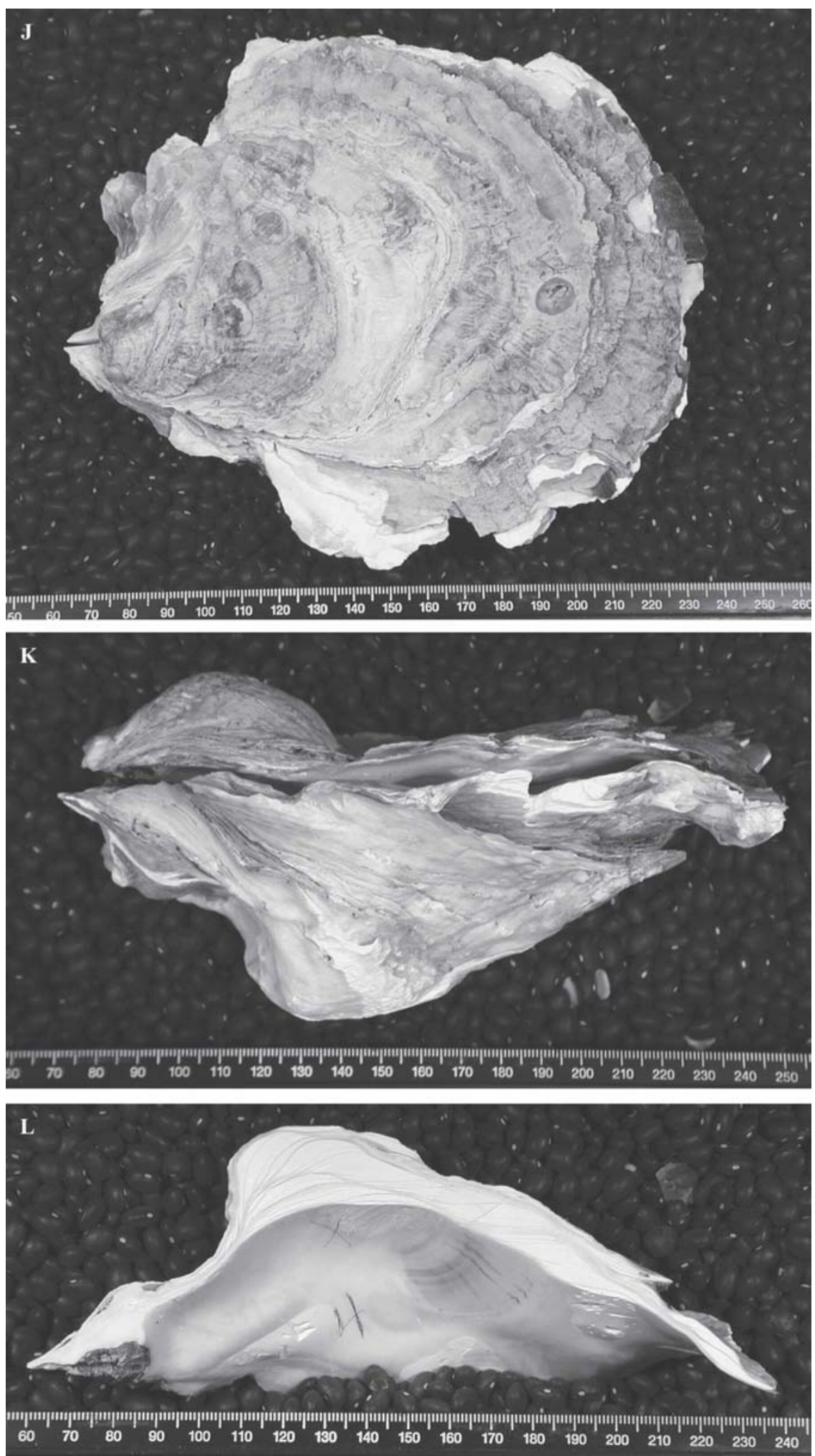

Figure 3. J to L, Rappahannock $C$. ariakensis, $\mathrm{SH}=180 \mathrm{~mm}$.

cally observed in the lower Rappahannock River (12-15 ppt, Stroup \& Lynn 1963), but both sites have salinities within the documented salinity tolerance of both species (e.g., Robinson 1992, Langdon \& Robinson 1996, Almeida et al. 1997, Calvo et al. 1999, 2001, Grabowski et al. 2004). Seasonally water temperatures in the Rappahannock River range from $4^{\circ} \mathrm{C}$ to $28^{\circ} \mathrm{C}$ (Stroup \& Lynn 1963). Laizhou Bay probably experiences a similar annual water temperature range based on documented annual water temperature profiles from adjacent habitats (Yellow Sea, Chung et al. 1993; South Korean coastal habitats, Kang et al. 2000). 


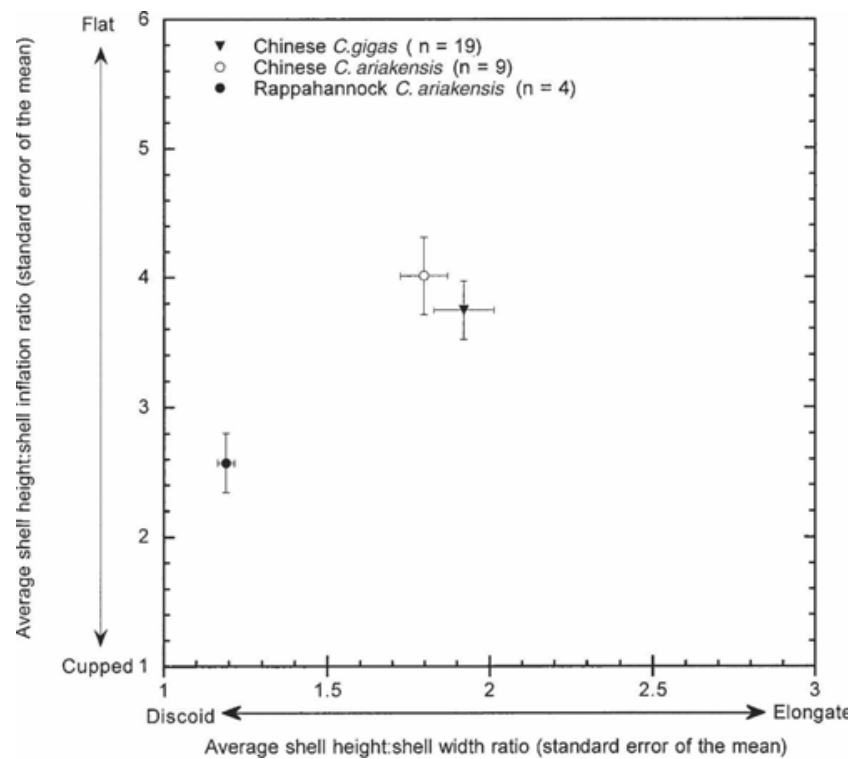

Figure 4. Average shell height $(\mathrm{SH})$ : shell width $(\mathrm{SW})$ ratios (with standard error of the mean) in relation to average shell height: shell inflation (SI) ratios (with standard error of the mean) for wild Chinese C. ariakensis and C. gigas and triploid Rappahannock $C$. ariakensis. Ratios of SH:SW and SH:SI for Rappahannock $C$. ariakensis are significantly less than these ratios for Chinese $C$. ariakensis (ANOVAs, $P<0.05)$. Ratios of SH:SW and SH:SI are similar for both Chinese species (ANOVAs, $P>0.05$ ).

Oysters have the potential to live in excess of $10 \mathrm{y}$ in the absence of disease pressure, environmental degradation or human fishing pressure (Richardson et al. 1993a, 1993b). Evolutionarily life history has evolved to ensure success of the species over the course of its lifetime; that is, each individual only has to reproduce successfully once to maintain the population. Recruitment in wild populations should not necessarily be expected every year given

TABLE 2.

Observed average shell height ( $\mathrm{SH})$ at age (standard error of the mean) and the observed range of shell heights at age for populations of Chinese $C$. gigas $(\mathrm{CHCg})$, Chinese $C$. ariakensis $(\mathrm{CHCa})$, and

Rappahannock $C$. ariakensis (RACa) examined in this study. Measurements were made from internal growth lines within the left valve of each individual. $\mathrm{SE}=$ standard error of the mean.

\begin{tabular}{ccccc}
\hline \hline Population & Age & $\boldsymbol{n}$ & $\begin{array}{c}\text { Average SH } \\
(\mathbf{m m}, \mathbf{S E}) \text { at Age }\end{array}$ & $\begin{array}{c}\text { Range of Observed } \\
\text { SH at Age (mm) }\end{array}$ \\
\hline \multirow{2}{*}{ CHCg } & 1 & 19 & $39.31(2.12)$ & $27-55$ \\
& 2 & 17 & $99.0(3.78)$ & $68-130$ \\
& 3 & 5 & $123.0(6.44)$ & $105-145$ \\
& 4 & 1 & $155(\mathrm{NA})$ & NA \\
$\mathrm{CHCa}$ & 1 & 9 & $42.7(3.3)$ & $27-57$ \\
& 2 & 9 & $101.42(6.05)$ & $75-134$ \\
& 3 & 6 & $136.83(4.74)$ & $120-152$ \\
& 4 & 4 & $167.25(5.23)$ & $155-179$ \\
$\mathrm{RACa}$ & 5 & 4 & $191.25(8.14)$ & $170-204$ \\
& 1 & 4 & $43.38(3.54)$ & $35-50$ \\
& 2 & 4 & $102.37(5.85)$ & $95-120$ \\
& 3 & 4 & $136.48(5.54)$ & $125-150$ \\
& 4 & 4 & $156.20(5.91)$ & $140-165$ \\
\hline
\end{tabular}

NA $=$ Not applicable

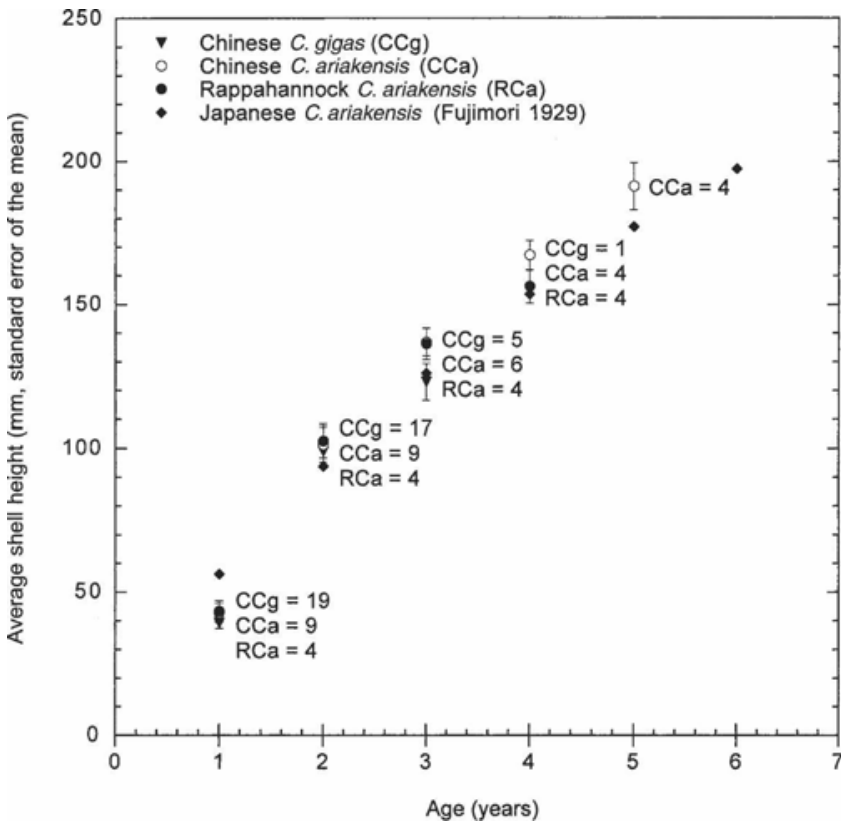

Figure 5. Average shell height ( $\mathrm{mm}$, standard error of the mean) at age for wild Chinese Crassostrea ariakensis and $C$. gigas and triploid $C$. ariakensis from the Rappahannock River, Virginia, United States in relation to reported shell-height at age for $C$. ariakensis in Ariake Bay, Japan (Fujimori 1929 reported by Cahn 1950). $n$ values for each species at age are presented to the right of each data point for Chinese and Rappahannock River animals.

the potential for interannual variability in recruitment to estuarine and marine benthic habitats (Loosanoff 1966, Powell \& Cummins 1985). The observed age distribution within wild collections (11 2-y-old C. gigas out of 19 total, four 5-y-old C. ariakensis out of 9 total) indicates that we are seeing cohorts. Size variation within

TABLE 3.

Summary of published shell-heights at age for $C$. ariakensis and C. gigas.

\begin{tabular}{|c|c|c|c|c|c|}
\hline \multicolumn{3}{|c|}{ C. ariakensis } & \multicolumn{3}{|c|}{ C. gigas } \\
\hline Age & $\begin{array}{c}\text { SH } \\
(\mathbf{m m})\end{array}$ & Location & Age & $\begin{array}{c}\text { SH } \\
(\mathbf{m m})\end{array}$ & Location \\
\hline \multirow[t]{4}{*}{1} & 55 & Japan $^{1}$ & 1 & $\begin{array}{c}20.1 \\
(\mathrm{SD} 6.1)\end{array}$ & Portugal $^{3}$ \\
\hline & 45 & Washington, US ${ }^{2}$ & & 24.4 & Mexico $^{4}$ \\
\hline & $45-50$ & Oregon, US ${ }^{2}$ & & 30 & Washington, US ${ }^{2}$ \\
\hline & $30-60$ & California, US ${ }^{2}$ & & $40-100$ & Oregon, US ${ }^{2}$ \\
\hline \multirow[t]{4}{*}{2} & 97 & Japan $^{1}$ & & 50 & California, US ${ }^{2}$ \\
\hline & 100 & Washington, US ${ }^{2}$ & 2 & $60-70$ & Portugal $^{3}$ \\
\hline & $65-90$ & Oregon, US ${ }^{2}$ & & 65.6 & Mexico $^{4}$ \\
\hline & 110 & California, $\mathrm{US}^{2}$ & & 110 & Washington, US ${ }^{2}$ \\
\hline 3 & 124 & Japan $^{1}$ & & 70-90 & Oregon, $\mathrm{US}^{2}$ \\
\hline 4 & 152 & Japan $^{1}$ & & 145 & California, $\mathrm{US}^{2}$ \\
\hline 5 & 179 & Japan $^{1}$ & & & \\
\hline 6 & 197 & Japan $^{1}$ & & & \\
\hline
\end{tabular}

${ }^{1}$ Ariake Bay, Japan. Fujimori 1929 from Cahn 1950.

${ }^{2}$ Puget Sound, Washington, US; Yasquina and Coos Bay, Oregon, US; Tomales Bay, California, US. Langdon and Robinson 1996.

${ }^{3}$ Rio de Averio and Mondego River estuary, Portugal. Almeida et al. 1997.

${ }^{4}$ Bahia de La Paz, Mexico. Arizpe 1996. 


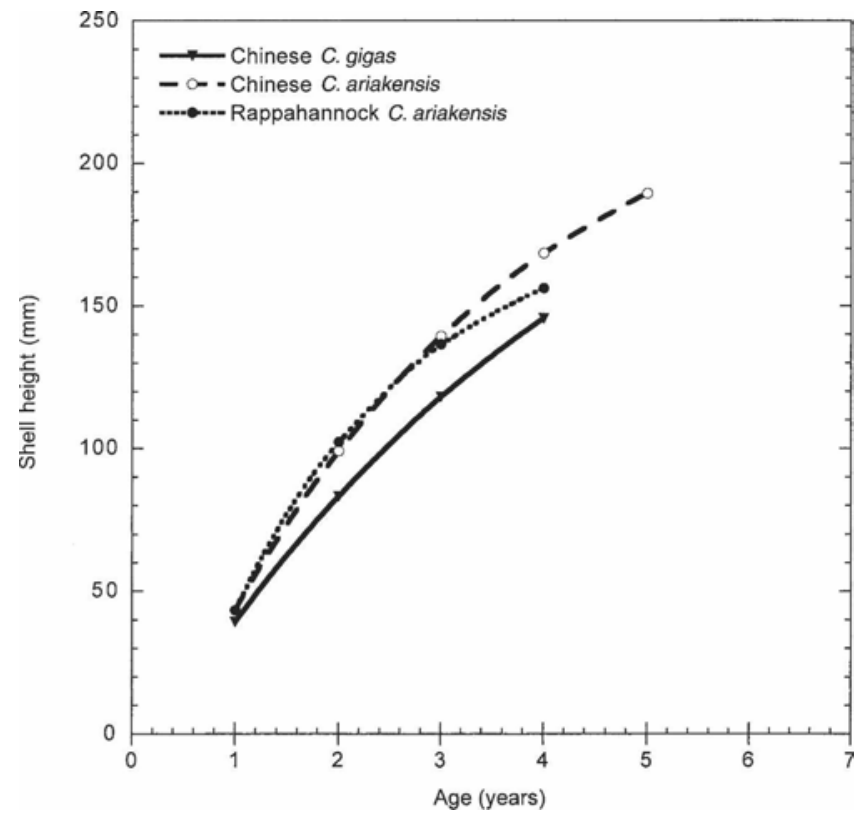

Figure 6. Fitted Von Bertalanffy growth curves for wild Chinese Crassostrea ariakensis and $C$. gigas and triploid $C$. ariakensis from the Rappahannock River, Virginia, United States.

a cohort may reflect time of settlement (early vs. late, see earlier), position in reef structure, or local conditions in the microhabitat in which the animal settled.

Comparisons of shell height at age and fitted growth curves present one element of comparison between oyster species within and across sites but these comparisons do not address the difference in inflation rates/cupping observed between the Rappahannock triploid $C$. ariakensis and the wild oysters of both species. The discoid, cupped Rappahannock oysters were larger in all dimensions than the Chinese oysters. When the four triploid Rappahannock C. ariakensis were shucked in May 2004, the meat fully filled the shell cavity with an average meat wet weight of $117.5 \mathrm{~g}$ (standard error of the mean, $\mathrm{SE}=7.43 \mathrm{~g}$ ) and average dry weight of $27.01 \mathrm{~g}$ ( $\mathrm{SE}=2.24 \mathrm{~g}$ ), J. Harding, unpublished data). This effective increase in shell volume has a direct correlation to the biomass of the animal and, in diploid individuals, fecundity. In the absence of tissue weights (wet or dry) for the diploid Chinese oysters, direct comparisons of biomass within a species (triploid vs. dipoloid), site (C. ariakensis versus $C$. gigas) or within species across sites are impossible, although it is probable that biomass trends for sites and species follow the observed trends in external morphology. In the absence of detailed habitat or ecological in-
TABLE 4.

Von Bertalanffy growth model coefficients (standard error), coefficient of determination $\left(\mathbf{R}^{2}\right)$, and mean square of residual values for populations of Chinese $\boldsymbol{C}$. ariakensis $(\mathrm{CHCa})$, Chinese $\boldsymbol{C}$. gigas (CHCg), and Rappahannock C. ariakensis (RACa). Residual mean square values are from the linear regression of observed versus predicted shell height (see text).

\begin{tabular}{ccccccc}
\hline \hline Population & Age/n & SHmax & $\mathbf{k}$ & $\mathbf{t}_{\mathbf{0}}$ & $\mathbf{R}^{2}$ & $\begin{array}{c}\text { Residual } \\
\text { Mean } \\
\text { Square }\end{array}$ \\
\hline \multirow{2}{*}{$\mathrm{CHCg}$} & $1 / 19,2 / 17$, & 158.6 & 0.68 & 0.58 & 0.89 & 383.22 \\
& $3 / 5,4 / 1$ & $(20.25)$ & $(0.20)$ & $(0.08)$ & & \\
$\mathrm{CHCa}$ & $1 / 9,2 / 9$, & 244.0 & 0.33 & 0.40 & 0.94 & 125.33 \\
& $3 / 6,4 / 4$, & $(30.41)$ & $(0.08)$ & $(0.13)$ & & \\
& $5 / 4$ & & & & & \\
$\mathrm{RACa}$ & $1-4 / 4$ & 183.0 & 0.55 & 0.51 & 0.96 & 92.19 \\
& & $(19.14)$ & $(0.15)$ & $(0.51)$ & & \\
\hline
\end{tabular}

formation for either collection site (e.g., annual temperature and salinity profiles, sediment characterization, population density) it is impossible to attribute observed differences in morphology to genetic (triploid vs. diploid), habitat, or ecological factors including competition for space or resources. Application of these growth trajectories to other oyster populations and habitats must include consideration of genetics and individual morphology (biomass) as well as ambient seasonal salinity and water temperature profiles for the habitats of interest.

\section{ACKNOWLEDGMENTS}

The authors thank Mr. Kirby A. Carpenter (Potomac River Fisheries Commission) for his interest in and support of the project. Drs. Mark Luckenbach (VIMS ESL) and Christopher Richardson (University of Wales-Bangor, Menai Bridge) collected the Chinese oysters in June 2004. Dr. Ryan Carnegie (VIMS EAAH) provided genetic identification of individual Chinese oysters. Dr. James Wesson (Virginia Marine Resources Commission) and Dr. Standish K. Allen, Jr. (VIMS ABC) made the triploid Rappahannock individuals available. Ms. Karen Hudson (VIMS ABC) and Dr. Allen provided access to original literature used in Zhou and Allen (2003). Dr. Allen and Ms. Melissa Southworth (VIMS Molluscan Ecology Program) provided helpful reviews of earlier versions of this manuscript. This is Contribution Number 2725 from the Virginia Institute of Marine Science. Funding for this project was provided by Potomac River Fisheries Commission and Maryland Department of Natural Resources.

\section{LITERATURE CITED}

Ahmed, M. 1971. Oyster species of west Pakistan. Pak. J. Zool. 3(2):229236.

Almeida, M., J. Machado \& J. Coimbra. 1997. Growth and biochemical composition of Crassostrea gigas (Thunberg) at three fishfarm earthen ponds. J. Shellfish Res. 16(2):455-462.

Arizpe, O. 1996. Secondary production, growth, and survival of the Pacific oyster Craassostrea gigas (Thunberg) in tropical waters, Bahia de La Paz, Mexico. J. Shellfish Res. 15(3):601-607.

Banks, M. A., D. Hedgecock \& C. Waters. 1993. Discrimination between closely related Pacific oyster species (Crassostrea) via mitochondrial
DNA sequences coding for large subunit rRNA. Mol. Mar. Biol. Biotechnol. 2:129-136.

Brown, D. \& P. Rothery. 1993. Models in Biology: mathematics, statistics, and computing. New York, NY: J. Wiley \& Sons. 688 pp.

Cahn, A. 1950. Oyster culture in Japan. United States Fish and Wildlife Service Fishery Leaflet No. 383. 80 pp.

Calvo, G., M. Luckenbach, S. Allen \& E. Burreson. 1999. Comparative field study of Crassostrea gigas (Thunberg 1793) and Crassostrea virginica (Gmelin 1791) in relation to salinity in Virginia. J. Shellfish Res. 18:465-473. 
Calvo, G., M. Luckenbach, S. Allen \& E. Burreson. 2001. Comparative field study of Crassostrea ariakensis (Fujita 1913) and Crassostrea virginica (Gmelin 1791) in relation to salinity in Virginia. J. Shellfish Res. 20:221-229.

Chen, Y., D. A. Jackson \& H. Harvey. 1992. A comparison of von Bertalanffy and polynomial functions in modelling fish growth data. Can. J. Fish. Aquat. Sci. 49:1228-1235.

Chung, E., S. Kim \& Y. Kim. 1993. Reproductive ecology of the purple shell, Rapana venosa (Gastropoda: Muricidae), with special reference to the reproductive cycle, depositions of egg capsules and hatchings of larvae. Korean J. Malacol. 9(2):1-15.

Devillers, N., A. Eversole \& J. Isely. 1998. A comparison of four growth models for evaluating the growth of the northern quahog Mercenaria mercenaria (L.). J. Shellfish Res. 17(1):191-194.

Fritz, L., L. Ragone \& R. Lutz. 1990. Microstructure of the outer shell layer of Rangia cuneata (Sowerby, 1831) from the Delaware River: Applications in the studies of population dynamics. J. Shellfish Res. 9(1): 205-213.

Gallucci, V. \& T. Quinn. 1979. Reparameterizing, fitting, and testing a simple growth model. Trans. Am. Fish. Soc. 108:14-25.

Grabowski, J., C. Peterson, S. Powers, D. Gaskill \& H. Summerson. 2004. Growth and survivorship of non-native (Crassostrea gigas and Crassostrea ariakensis) versus native Eastern oysters (Crassostrea virginica). J. Shellfish Res. 23(3):781-793.

Haddon, M. 2001. Modelling and quantitative methods in fisheries. Boca Raton, FL: Chapman and Hall/CRC press. 406 pp.

Hallerman, E., S. Leffler, S. Mills \& S. K. Allen, Jr. 2002. Aquaculture of triploid Crassostrea ariakensis in Chesapeake Bay: a symposium report. Maryland Sea Grant Extension Publication UM-SG-TS-2002-01 and Virginia Sea Grant Publication VSG-02-03. 20 pp.

Jones, D., I. Quitmyer, W. Arnold \& D. Marelli. 1990. Annual shell banding, age, and growth rate of hard clams (Mercenaria spp.) from Florida. J. Shellfish Res. 9(1):215-225.

Kang, C., M. Park, P. Lee, W. Choi \& W. Lee. 2000. Seasonal variation in condition, reproductive activity, and biochemical composition of the Pacific oyster, Crassostrea gigas (Thunberg), in suspended culture in two coastal bays of Korea. J. Shellfish Res. 19(2):771-778.

Kirby, M., T. Soniat \& H. Spero. 1998. Stable isotope sclerochronology of Pleistocene and recent oyster shells (Crassostrea virginica). Palaios 13:560-569.

Langdon, C. \& A. Robinson. 1996. Aquaculture potential of the Suminoe oyster (Crassostrea ariakensis Fugita 1913). Aquaculture 144:321328.

Loosanoff, V. 1966. Time and intensity of setting of the oyser, Crassostrea virginica, in Long Island Sound. Biol. Bull. 130:211-227.

Lutz, R. \& D. Rhoads. 1980. Growth patterns within the molluscan shell: an overview.. Skeletal growth of aquatic organisms. In: D. C. Rhoads \& R. A. Lutz, editor. Biological records of environmental change. New York, NY: Plenum Press. pp. 203-254.

Mann, R. 1981. The role of introduced bivalve mollusc species in mariculture. J. World Maricult. Soc. 14:546-559.
Mann, R., E. Burreson \& P. Baker. 1991. The decline of the Virginia oyster fishery in Chesapeake Bay: Considerations for introduction of a nonendemic species, Crassostrea gigas (Thunberg, 1973). J. Shellfish Res. 10:379-388

Pannella, G. \& C. MacClintock. 1968. Biological and environmental rhythms reflected in molluscan shell growth. Mem. Journ. Paleo. 42: 64-80.

Perdue, J. \& G. Erickson. 1984. A comparison of the gametogenic cycle between the Pacific oyster Crassostrea gigas and the Suminoe oyster Crassostrea rivularis in Washington State. Aquaculture 37:231-237.

Powell, E. \& H. Cummins. 1985. Are molluscan maximum life spans determined by long-term cycles in benthic communities? Oecologica. 67:177-182.

Richardson, C., S. Collis, K. Ekaratne, P. Dare \& D. Key. 1993a. The age determination and growth rate of the European flat oysters, Ostrea edulis, in British waters determined from acetate peels of umbo growth lines. ICES J. Mar. Sci. 50:493-500.

Richardson, C., R. Seed, E. Al-Roumaihi \& L. McDonald. 1993b. Distribution, shell growth, and predation of the New Zealand oyster, Tiostrea (=Ostrea) lutaria Hutton, in the Menai Strait, North Wales. J. Shellfish Res. 12(2):207-214.

Richardson, C. R. 2001. Molluscs as archives of environmental change. Oceanography and Marine Biology An Annual Review. 39:103-164.

Robinson, A. 1992. Gonadal cycle of Crassostrea gigas kumamoto (Thunberg) in Yaquina Bay, Oregon and optimum conditions for broodstock oysters and culture. Aquaculture 106:89-97.

Ropes, J. W. 1985. Modern methods used to age oceanic bivalves. Nautilus 99(2-3):53-57.

Sephton, T. \& C. Bryan. 1990. Age and growth rate determinations for the Atlantic surf clam, Spisula solidissima (Dillwyn, 1817), in Prince Edward Island, Canada. J. Shellfish Res. 9(1):177-185.

Shatkin, G., S. Shumway \& R. Hawes. 1997. Considerations regarding the possible introduction of the Pacific oyster (Crassostrea gigas) to the Gulf of Maine: A review of global experience. J. Shellfish Res. 16(2): 463-477.

Stroup, E. \& R. Lynn. 1963. Atlas of salinity and temperature distributions in Chesapeake Bay 1952-1961 and seasonal averages 1949-1961. Graphical summary report 2. The Chesapeake Bay Institute, Johns Hopkins University. Report 63-1.

Torigoe, K. 1981. Oysters in Japan. Journal of Science of the Hiroshima University. Div. 1 (Zoology) Ser. B. 29(2):291-419.

von Bertalanffy, L. 1938. A quantitative theory of organic growth. Hum. Biol. 10:181-213.

Wakiya, Y. 1929. Japanese food oysters. Japanese Journal of Zoology. 2(3):359-367.

Zar, J. H. 1996. Biostatistical analysis, 3rd edition. New Jersey: Prentice Hall.

Zhang, X. \& Z. Lou. 1956. Oyster. Bull. Biol./Sheng Wu Zue Bao (Chinese) 2:27-32.

Zhou, M. \& S. Allen. 2003. A review of the published work on Crassostrea ariakensis. J. Shellfish Res. 22(1):1-20. 